\title{
Penerapan Pengolahan Kelapa Menjadi Minyak Murni (VCO) Menggunakan Teknologi Pemanas Buatan
}

\author{
Khusna Dwijayanti, Eko Darmawanto, Khotibul Umam \\ Fakultas Sains dan Teknologi, UNISNU Jepara \\ khusna.dwijayanti@gmail.com
}

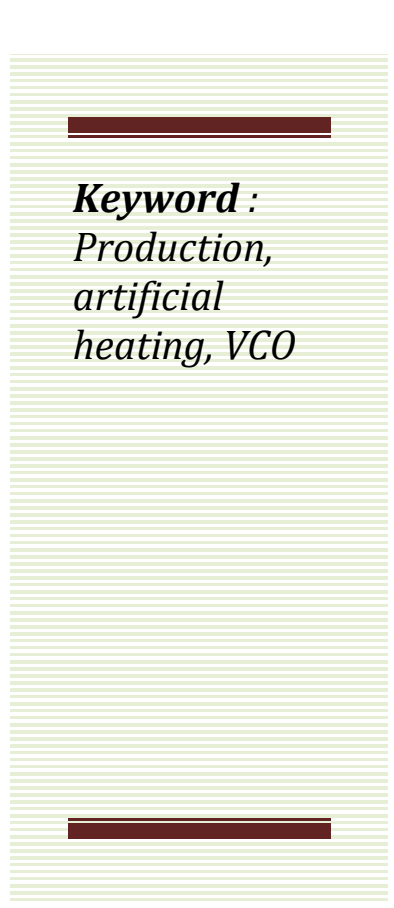

\begin{abstract}
This community service activities aim to: 1) increase the creativity and innovation of members to make processed coconut products; 2) increase partner understanding of Virgin Coconut Oil (VCO) processing that is able to provide economic and health impacts; 3) increase the ability of members in designing the packaging for coconut products. This community service implementation method is an empowerment model for partners, namely PKK RT 02 RW 07 Demaan group, Jepara sub-district, with the following steps: 1) Preparation Stage; 2) Assessment Phase; 3) Stage of Alternative Planning Programs or Activities; 4) Formulation Phase of the Action Plan; 5) Stage of Implementation (Implementation) of Programs or Activities; 6) Evaluation Phase. The results obtained from this activity include: 1) Partners have creativity in running the PKK group program; 2) partners have the ability to process $V C$ ) as a means of improving the quality of the PKK program; 3) Partners in the process of producing VCO; 4) Partners understand the benefits of VCO for economic and health;
\end{abstract}

\section{Abstrak}

Kegiatan Pengabdian Masyarakat bertujuan untuk: 1) meningkatkan kreatifitas dan inovasi anggota untuk membuat produk olahan kelapa; 2)

Kata Kunci :

Produksi,

Pemanas

buatan, VCO meningkatkan pemahaman mitra tentang pengolahan VCO yang mampu memberikan dampak ekonomis dan kesehatan; 3) meningkatkan kemampuan anggota dalam teknik pembuatan Virgin Coconut Oil (VCO) menggunakan teknologi pemanas buatan. Metode pelaksanaan pengabdian masyarakat ini adalah model pemberdayaan kepada mitra yaitu kelompok PKK RT 02 RW 07 Demaan kecamatan Jepara kota dengan langkah-langkah sebagai berikut: 1) Tahap Persiapan; 2) Tahap Assesment; 3) Tahap Perencanaan Alternatif Program atau Kegiatan; 4) Tahap Pemformulasian Rencana Aksi; 5) Tahap Pelaksanaan (Implementasi) Program atau Kegiatan; 6) Tahap Evaluasi. Hasil yang didapatkan dari kegiatan ini diantaranya : 1) Mitra memikliki kreativitas dalam menjalankan program kelompok PKK; 2) mitra memiliki kemampuan pengolahan VCO sebagai sarana meningkatkan mutu program PKK; 3) Mitra dalam melakukan proses produksi VCO; 4) Mitra memahami manfaat VCO dari segi ekonomi dan kesehatan; 


\section{PENDAHULUAN}

1. Latar Belakang

PKK atau pembinaan kesejahteraan keluarga merupakan program yang diberdayakan oleh pemerintah dalam bentuk organisasi kemasyarakatan sudah sejak lama, tak terhitung jumlah dan hasil serapan yang ada di wilayah indonesia secara nasional (Cucu, 2007). Meski begitu masih banyak dari 10 program pokok PKK yang tidak berjalan sebagaimana mestinya, banyak faktor dan penyebab program PKK yang seharusnya menjadi ujung tombak pemberdayaan masyarakat melalui komunitas yang mayoritas anggotanya adalah Ibu rumah tangga ini menjadi cenderung seperti berjalan ditempat. Salah satu diantaranya program PKK yang implementasinya tidak sesuai dengan kebutuhan di lingkungan atau singkatnya tidak ada sinkronisasi antara teori dan praktik di lapangan. Satu hal yang juga masih belum banyak dicapai PKK adalah menciptakan dampak ekonomis bagi anggota.

Selama ini program PKK yang dapat menyentuh lapisan masyarakat bawah hanya berfokus pada pogram perencanaan kesehatan dan gotong royong seperti program pos pelayanan terpadu atau posyandu serta program PNPM Mandiri yang sempat bergema dan pengelolaannya melibatkan anggota PKK seperti yang terjadi PKK RT 02 RW 07 Demaan Desa Demaan Kecamatan Jepara Kota. Pemberdayaan program yang belum tepat membuat capaian program kelompok PKK RT 02 RW 07 Demaan mengalami keterserapan program yang kurang memadai sehingga diperlukan asupan program yang mampu mensinergikan setidaknya beberapa program pokok PKK antara program pendidikan keterampilan, dan berkehidupan koperasi sehingga mampu dimunculkan sebuah kompetensi epik yang mampu memberikan dampak ekonomis sekaligus keterampilan yang mampu menghasilkan produk yang dapat dimitrakan dalam kapasitas penjualan yang berijin dan terstandar dengan baik baik. Tema produk olahan menjadi usulan dari anggota PKK RT 02 RW 07 Demaan maka tim Pengabdian Unisnu bersinergi dalam mencari dan mengangkat potensi Jepara yang melimpah sehingga setelah melakukan beberapa kali evaluasi, kelapa merupakan produk yang tepat karena ketersediaan Kelapa di Desa Demaan melimpah. Kelapa dapat diolah menjadi tiga produk dengan satu kali proses pemanasan yakni, santan, minyak goreng dan minyak murni atau virgin coconout oil. Transfer of knowlage kepada anggota PKK dapat dilakukan karena pengolahan VCO termasuk mudah. 


\section{Tujuan}

Berdasarkan pemaparan yang telah dikemukakan pada analisis situasi terdapat beberapa permasalahan yang dihadapi oleh mitra, sehingga ditentukan prioritas tujuan utama Pengabdian yaitu:

a. Mengembangkan produk olahan yang mampu memberikan dampak ekonomis secara langsung berupa produk olahan kelapa berupa minyak kelapa murni (VCO) yang terstandar

b. Meningkatkan pengetahuan dan kemampuan mitra dalam pengolahan kelapa

c. Mengenbangkan pengemasan produk olahan minyak murni (VCO)

\section{Manfaat}

Berdasarkan tujuan yang dirumuskan, dalam kegiatan pengabdian masyarakat ini mempunyai beberapa manfaat sebagai berikut:

a. Mitra mampu menghasilkan produk minyak kelapa murni (VCO) yang terstandar mutu pengolahan

b. Mitra memiliki desain pengemasan minyak kelapa murni (VCO) yang menarik dan terstandar pemasaran

Berikut gambaran detil tujuan dan manfaat dalam pengabdian masyarakat;

Tabel 1. Permasalahan, Tujuan dan Manfaat

\begin{tabular}{|l|l|lr|l|}
\hline No & \multicolumn{1}{|c|}{ Permasalahan } & \multicolumn{2}{|c|}{ Tujuan } & \multicolumn{1}{c|}{ Manfaat } \\
\hline 1 & $\begin{array}{l}\text { Produk olahan yang } \\
\text { mampu memberikan } \\
\text { dampak ekonomis }\end{array}$ & $\begin{array}{l}\text { Pengolahan kelapa } \\
\text { menjadi minyak kelapa } \\
\text { murni }\end{array}$ & $\begin{array}{l}\text { Produk minyak kelapa murni } \\
\text { (VCO) }\end{array}$ \\
\hline 2 & $\begin{array}{l}\text { Pengetahuan anggota PKK } \\
\text { RT 02 RW 07 Demaan } \\
\text { kurang memadai dalam } \\
\text { pengolahan kelapa }\end{array}$ & $\begin{array}{l}\text { Pendampingan teknis } \\
\text { pengolahan } \\
\text { menggunakan pelapa } \\
\text { buatan }\end{array}$ & $\begin{array}{l}\text { Pelatihan pemurnian minyak } \\
\text { kelapa dengan teknologi } \\
\text { pemanas buatan }\end{array}$ \\
\hline 3 & $\begin{array}{l}\text { Pengemasan produk } \\
\text { olahan minyak murni }\end{array}$ & Pelatihan desain kemasan & Stiker kemasan botol \\
\hline
\end{tabular}

\section{LANDASAN TEORETIS}

\section{Virgin Coconut Oil (VCO)}

Virgin Coconout Oil atau lebih dikenal dengan VCO merupakan minyak yang dihasilkan dari pemurnian santan kelapa dengan metode tertentu untuk memisahkan unsur -unsur kimiawi secara bertahap (Silaban, 2014). Pada dasarnya VCO bersifat bening disebabkan hasil pemisahan unsur kimiawi yang bertahap dengan pengolahan yang benar, VCO tidak berasa dan berbau jika pengolahannya benar. Dengan kandungan asam laurat yang tinggi menjadikan VCO sebuah produk yang mampu difungsikan untuk banyak 
keperluan medis dan kecantikan (Suaniti, 2014).

2. Pemanas buatan

Pemanas buatan merupakan pengkondisian suhu dengan tempratur hangat dan bertahap meningkat dengan pengaturan suhu secara konstan serta pemanfaatannya sesuai dengan kebutuhan (Yahya, M. (2015). Dalam praktiknya pemanas buatan dapat diperoleh dengan peralatan sederhana maupun yang berada dipasaran, dengan teknik dan cara yang berbeda-beda tetap tidak merubah pola konsistensi dan fungsi dari pemanas buatan.

Sistem kerja pemanas buatan sangat sederhana yakni dengan cara menaikkan suhu dengan mengurangi kadar oksigen dalam udara atau kita kenal dengan udara kering, inilah yang kemudian menyebabkan terjadinya reaksi kimiawi yang dapat menaikkan tempratur udara ke level kering lebih sederhananya panas merupakan energi yang berpindah akibat perubahan suhu.

\section{METODE PELAKSANAAN}

1. Rencana Kegiatan.

Persiapan kegiatan yang dilakukan yaitu Tim melakukan koordinasi dengan stakeholders terkait seperti Ketua PKK Induk Desa Demaan, Ketua Kelompok PKK RT 02 RW 07
Demaan, anggota kelompok PKK RT 02 RW 07 Demaan. Selain itu juga tim berkoordinasi dengan LPPM Unisnu dan menyusun bahan/materi/modul pelatihan.

2. Perekrutan peserta.

Peserta yang mengikuti pelatihan sebanyak sejumlah anggota aktif yakni 15 orang yang terdiri dari ibu rumah tangga dan remaja dalam upaya mengatasi permasalahan yang dihadapi.

3. Pemberian Pelatihan dan Pendampingan kreatifitas kepada mitra.

4. Pelatihan. Pelatihan yang diberikan kepada mitra meliputi

a. Pelatihan teknis proses produksi minyak kelapa murni (VCO) dengan urutan sebagai berikut:

- Persiapan bahan kelapa mentah yang akan diolah menjadi minyak kelapa murni

- Proses memarut kelapa menggunakan peralatan parut mesin atau pemarut kelapa manual

- Menyiapkan peralatan wadah penampungan hasil parutan kelapa dan menambahkan air sesuai ketentuan tergantung dari jumlah kelapa yang 
diproduksi untuk menjadi santan

- Setelah santan diperoleh langkah selanjutnya adalah menyimpan santan dalam wadah yang tertutup rapat

- Tempat santan yang telah ditutup rapat kemudian dimasukkan dalam wadah besar (drum) atau sejenis yang didalamnya telah diberikan kain pelapis woll untuk mendapatkan suhu stabil 20$25^{\circ} \mathrm{C}$

- Dalam drum tempat santan diletakkan dalam posisi tengah dan dilapisi kain atau kain jenis wool untuk menyerap panas dari proses peragian sehingga panas sehingga meminimalkan proses suhu berlebih yang dikeluarkan oleh peragian

- Selanjutnya drum ditutup rapat dan di diamkan 8-10 jam

- Setelah 8-10 jam drum pemanas di buka dan santan diambil dari drum

- Pada bagian atas santan terdapat 3 endapan dan yang diambil untuk disaring adalah yang bagian minyak
- Minyak diambil menggunakan sendok atau alat sejenis kemudian disaring menggunakan kertas saring atau kain steril untuk memisahkan kotoran yang ikut dalam minyak kelapa murni, lakukan berulang setidaknya $3 x$ untuk mendapatkan minyak yang jernih

- Masikkan minyak hasil penyaringan dalam botol untuk selanjutnya dilakukan pengemasan dan segel kemasan

b. Pelatihan. Dilakukan dengan metode ceramah teori dan praktik teknis desain kemasan secara praktis dengan urutan sebagai berikut:

- Penyiapan bahan foto kelapa untuk dilakukan editing sebagai visual identity (identitas visual pendukung band)

- Penyiapan materi pendukung berupa informasi dalam kemasan terdiri dari: Nama produk (brand name), tempat produksi, standarisasi produk, manfaat produk, no registrasi produk dari BP POM (jika ada), tanggal kadaluarsa 
- Persiapan alat desain menggunakan komputer /laptop dan software corel draw

- Proses editing menggunakan software

- Cetak desain dengan kertas stiker

- Penempelan label pada botol kemasan

5. Partisipasi mitra.

Partisipasi mitra secara aktif mengikuti semua kegiatan yang dilakukan baik untuk mengkaji permasalahan, membuat VCO yang memenuhi standar mutu produksi. Strategi yang ditempuh untuk meningkatkan partisipasi mitra adalah:

a. Pendekatan personal kepada mitra dengan tujuan mendapatkan informasi strategis terkait dengan kemampuan kerja team yang diharapkan oleh tim pengabdian UNISNU.

b. Penyiapan tempat pengolahan sesuai dengan standar pengolahan mutu produksi yang memadai dengan tujuan akan dihasilkan produk olahan kelapa berupa minyak kelapa murni (VCO) yang sesuai standart c. Kontrol SDM mitra terkait dengan standart operasional prosedur yang harus dipenuhi (Setiaji, 2006)

d. Skill treatment terkait K3 yang harus dipenuhi melalui penyuluhan.

e. Pelatihan dan pendampingan desain kemasan

f. Merangkul mitra pemasaran untuk dapat bekerjasama dari sisi pemasaran produk olahan yang sudah jadi

6. Evaluasi Kegiatan

Pelatihan pengolahan produk kelapa menjadi minyak kelapa murni (VCO) diberikan dengan metode ceramah, diskusi, tanya jawab, simulasi/ demonstrasi, pembuatan minyak kelapa murni (VCO) dan panduan prosedur teknik produksi. Dalam pelatihan ini diberikan materi dan konsep-konsep terkait minyak kelapa murni (VCO) sesuai dengan kebutuhan dan target pasar.

Diskusi dan demonstrasi diimbangi dengan keaktifan peserta, mulai dari mengajukan pertanyaan hingga membawa bahan dan perlengkapan secara mandiri meskipun dari pihak penyuluh sudah menyediakan. Kegiatan pelatihan ini bersifat kooperatif, diharapkan setiap peserta termotivasi untuk ikut memproduksi. 
Manfaat yang dapat dipetik oleh anggota kelompok PKK dengan diadakannya pelatihan antara lain: menambah pengetahuan dan keterampilan untuk memproduksi minyak kelapa murni (VCO). Dengan bahan-bahan yang melimpah dan murah, anggota Kelompok PKK RT 02 RW 07 Demaan dapat memproduksi minyak kelapa murni (VCO) sesuai dengan kebutuhan. Dengan demikian, ketersediaan minyak kelapa murni (VCO) dapat meningkatkan kualitas ekonomi anggota Kelompok PKK RT 02 RW 07 Demaan sehingga memotivasi perkembangan program kelompok PKK.

Kegiatan kooperatif yang mengusung pola gotong royong akan mampu menumbuhkan rasa percaya diri dan membentuk citra anggota Kelompok PKK RT 02 RW 07 Demaan yang positif. Kondisi tersebut sangat mendukung anggota Kelompok PKK RT 02 RW 07 Demaan dalam mengembangkan rasa percaya diri dalam produksi minyak kelapa murni (VCO). Dengan memberikan kesempatan pada para Kelompok PKK RT 02 RW 07 Demaan untuk bersosialisasi, berkomunikasi dan berbagi ilmu pengolahan produk. Proses pembuatan minyak kelapa murni (VCO) ini berfungsi memfasilitasi pengembangkan program yang bersinergi dengan kebutuhan ekonomi dan kesehatan dengan lingkungan di sekitar.

\section{HASIL DAN PEMBAHASAN}

1. Pelatihan teknis proses produksi minyak kelapa murni (VCO)

a. Persiapan bahan kelapa mentah yang akan diolah

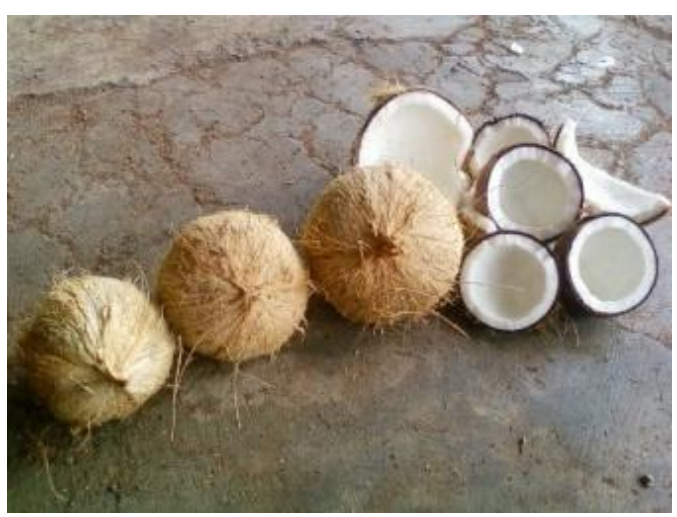

Gambar 1. Kelapa yang akan diparut

b. Pemarutan kelapa menggunakan peralatan parut mesin atau pemarut kelapa manual

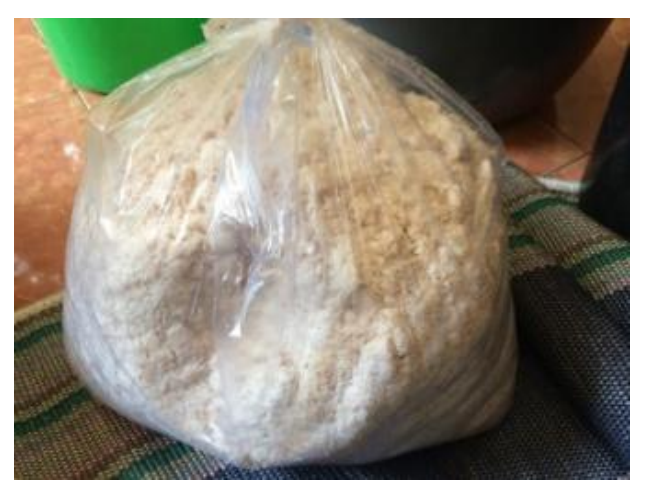

Gambar 2. Kelapa setelah diparut

c. Persiapan wadah penampungan hasil parutan kelapa dan menambahkan air sesuai ketentuan tergantung dari 


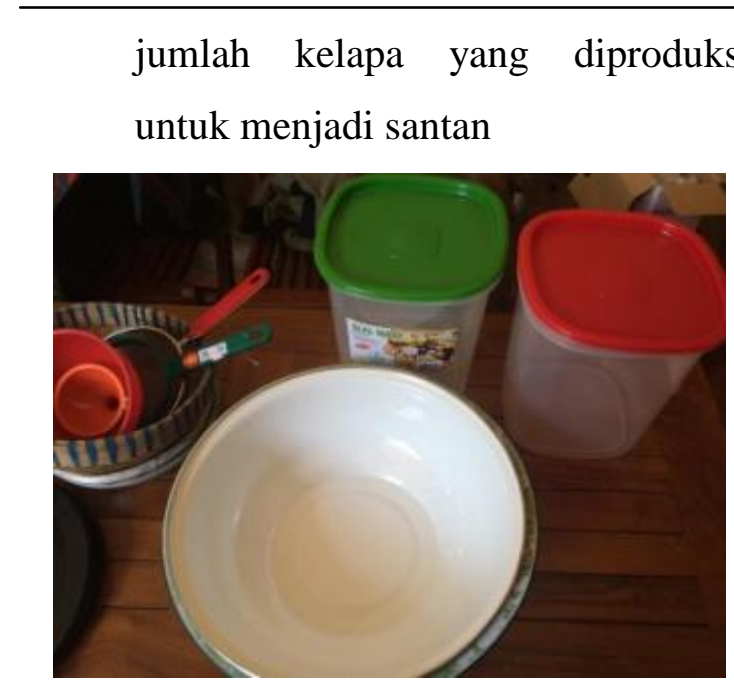

Gambar 3. Peralatan pengolah Minyak $\mathrm{VCO}$

d. Pemerasan santan

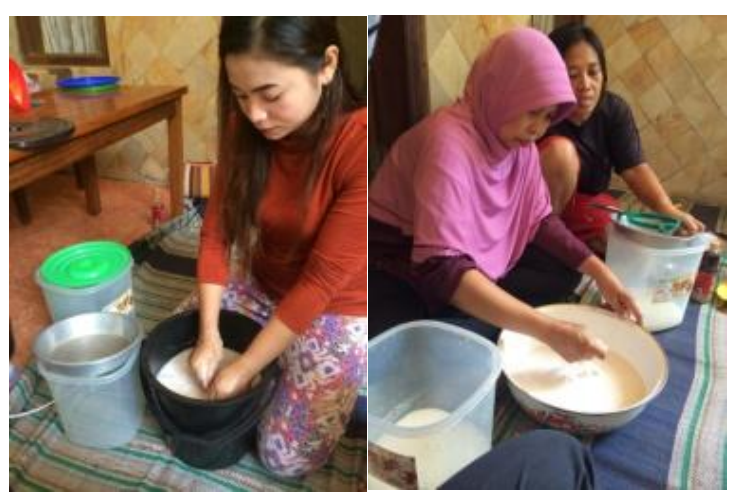

Gambar 4. pemerasan santan dan penyimpanan

e. Santan yang telah didapat kemudian dimasukkan dalam wadah besar atau sejenis yang didalamnya telah diberikan kain yang sebelumnya dilakukan pemanasan buatan dengan cara ditambahkan ragi untuk meningkatkan suhu pemanasan buatan sekitar 20-25 $\mathrm{C}$ (Pontoh, 2011).

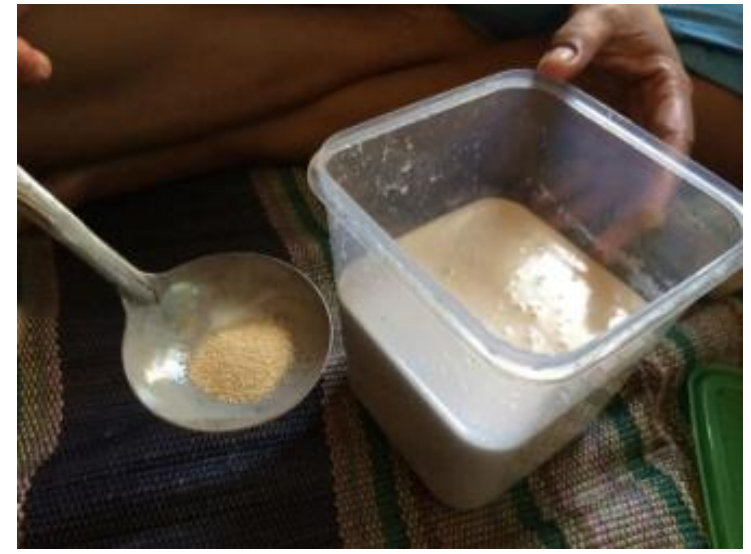

Gambar 5. Penambahan ragi sebagai pemanas buatan

f. Dalam tempat santan diletakkan dalam posisi tengah dan dilapisi kain kaos atau kain jenis wool untuk menyerap panas hasil peragian sehingga panas tidak dapat bersentuhan langsung dengan santan sehingga meminimalkan proses suhu berlebih atau tanpa kain cukup dengan suhu ruang (Thamrin, 2016)..

g. Selanjutnya wadah ditutup rapat dan di diamkan 8-10 jam (Moeksin, 2008).

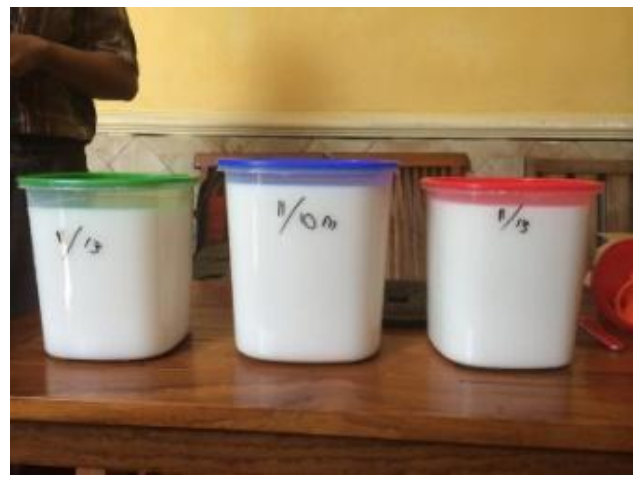

Gambar 6.Pengendapan santan kelapa 
h. Setelah 8-10 jam wadah pemanas di buka dan santan diambil dari tempat

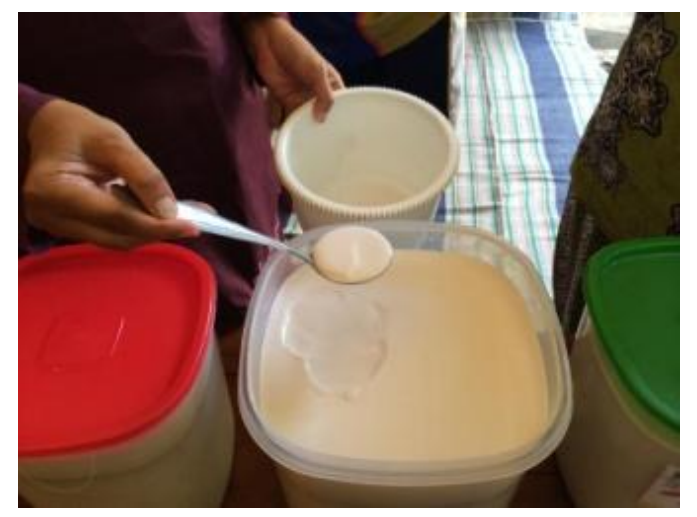

Gambar 7. pengambilan endapan santan

i. Pada bagian atas santan terdapat 3 endapan dan yang diambil untuk disaring adalah yang bagian minyak

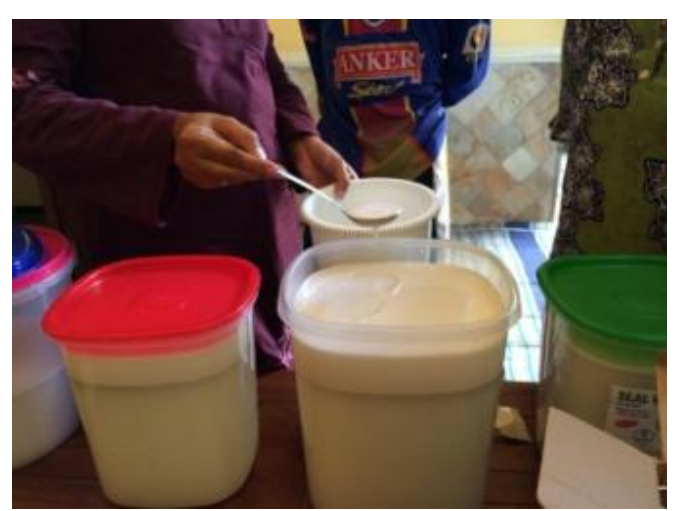

Gambar 8. Hasil endapan santan

j. Minyak diambil menggunakan sendok atau alat sejenis kemudian disaring menggunakan kertas saring atau kain steril untuk memisahkan kotoran yang ikut dalam minyak kelapa murni, lakukan berulang setidaknya $3 x$ untuk mendapatkan minyak yang jernih (Hapsari, 2013)

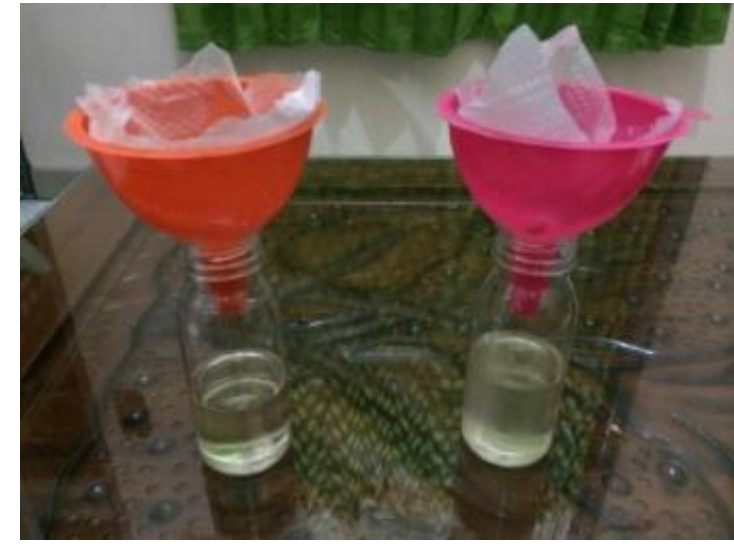

Gambar 9.Penyaringan Minyak VCO

k. Masukkan minyak hasil penyaringan dalam botol untuk selanjutnya dilakukan pengemasan dan segel kemasan

2. Pelatihan teknis desain kemasan secara praktis.

a. Penyiapan bahan foto kelapa untuk dilakukan editing sebagai visual identity (identitas visual pendukung band)

b. Penyiapan materi pendukung berupa informasi dalam kemasan terdiri

c. Persiapan alat desain menggunakan komputer /laptop dan software corel draw

d. Proses editing menggunakan software

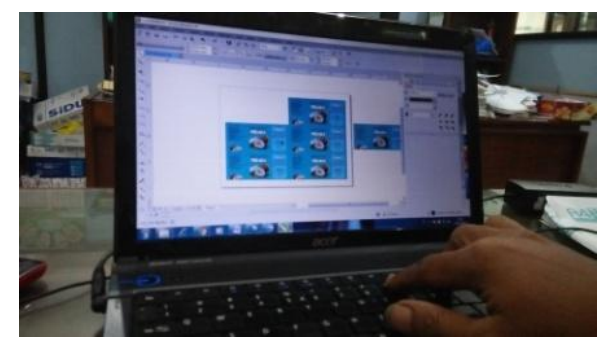

Gambar. 10. Editing kemasan 
e. Cetak desain dengan kertas stiker

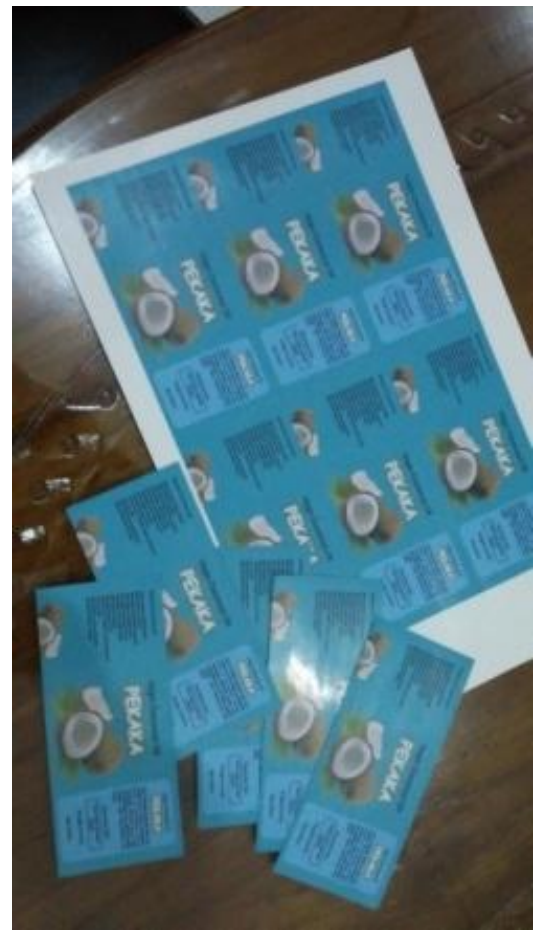

Gambar 11. Pencetakan label kemasan oleh Kelompok PKK

f. Penempelan label pada botol kemasan

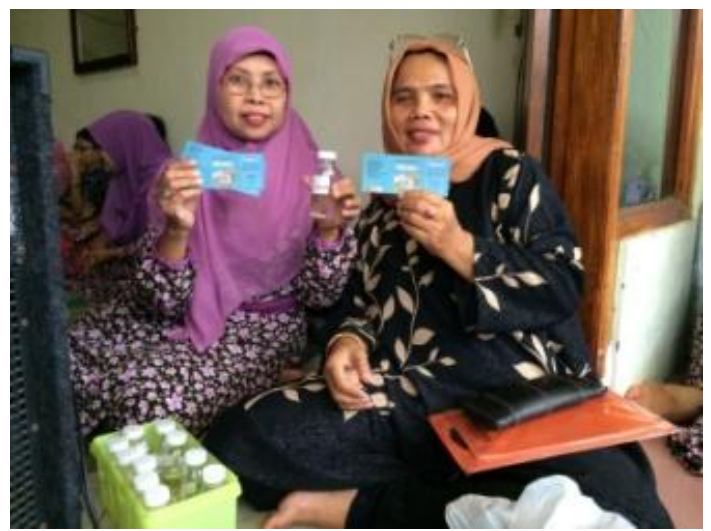

Gambar. 12. Penempelan label kemasan

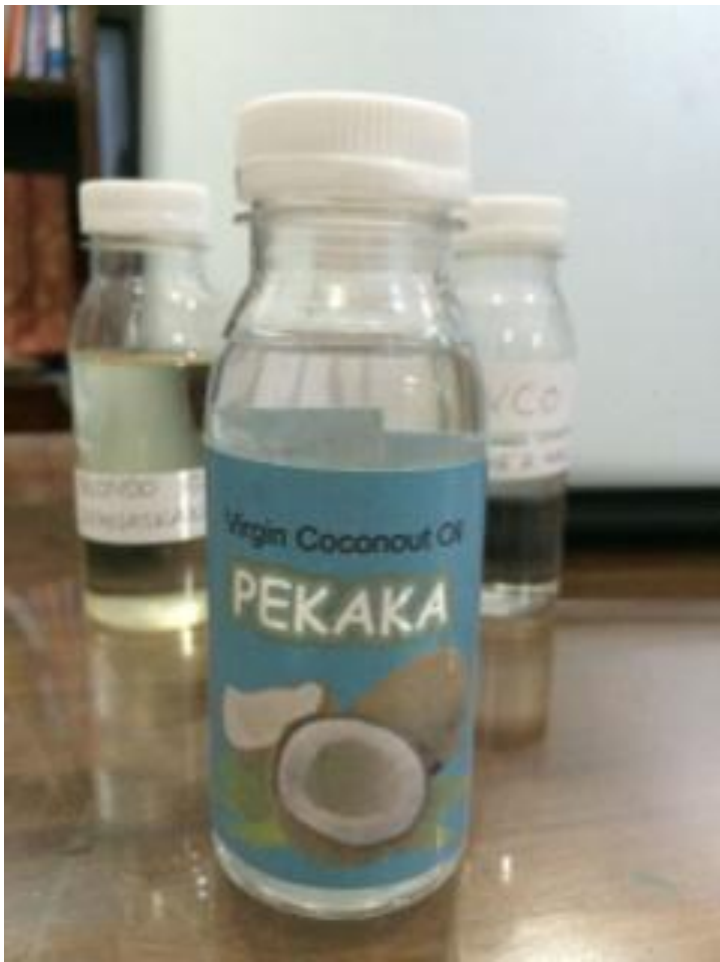

Gambar. 5.13. Hasil label kemasan dan produk jadi

\section{SIMPULAN}

Hasil yang didapatkan dari kegiatan ini adalah:

1. Meningkatnya kreatifitas anggota PKK sebagai upaya menunjang kegiatan program kelompok PKK;

2. Mitra memiliki kemampuan pengolahan minyak kelapa murni (VCO) sebagai sarana meningkatkan mutu program PKK;

3. Meningkatnya kemampuan mitra dalam melakukan proses produksi minyak kelapa murni (VCO);

4. Meningkatnya pemahaman mitra terhadap manfaat minyak kelapa murni (VCO) dari sisi pemenuhan ekonomi dan kesehatan; 
5. Produk minyak murni VCO dengan brand PEKAKA, Produk Minyak goreng murni dengan brand PEKAKA,

6. Pengembangan kreatifitas perekonomian kelompok PKK RT 02 RW 07 Demaan melalui produk kesehatan, Packaging kemasan produk VCO dan minyak goreng PEKAKA

\section{UCAPAN TERIMA KASIH}

Tim Pengabdian mengucapkan terima kasih atas terlaksananya pengabdian kepada:

1. LPPM Unisnu Jepara

2. Ketua Tim Penggerak dan Anggota PKK RT 02 RW 07 Demaan Jepara

3. Tutor pengisi kegiatan pengabdian.

\section{Daftar Pustaka}

Cucu, S. (2007). Buku saku kader PKK.

Tim Penggerak PKK Kabupaten Bekasi.

Hapsari, N., \& Welasih, T. (2013). Pembuatan virgin Coconut Oil (VCO) dengan Metode Sentrifugasi. REKAPANGAN, 4(2)

Ketaren, S. (1986). Pengantar Teknologi Minyak dan Lemak Pangan. Universitas Indonesia-Press. Jakarta.
Moeksin, R., Rahmawati, Y., \& Rini, P. (2008). Pengaruh Penambahan Papain terhadap Kualitas VCO dengan Metode Enzimatis, Sentrifugasi dan Pemanasan. Jurnal Teknik Kimia, 15(1).

Pontoh, J., \& Makasoe, L. (2011). Perbandingan beberapa metode pembuatan metil ester dalam analisa asam lemak dari virgin coconut oil (VCO). Jurnal Ilmiah Sains, 11(2), 241-247.

Setiaji, B. (2006). Membuat VCO (Virgin Coconut Oil) Berkualitas Tinggi.Jakarta. PT. Gramedia Pustaka Utama.

Silaban, R., Manullang, R. S., \& Hutapea, V. (2014). Pembuatan Virgin Coconut Oil (VCO) Melalui Kombinasi Teknik Fermentasi dan Enzimatis Menggunakan Ekstrak Nenas. Jurnal Pendidikan Kimia, 6(1), 91-100.

Suaniti, N. M., Manurung, M., \& Hartasiwi, N. (2014). Uji Sifat Virgin Coconut Oil (VCO) Hasil Ekstraksi Enzimatis Terhadap Berbagai Produk Minyak Kelapa Hasil Publikasi. Jurnal Kimia, 8(2).

Thamrin, G. A. (2016). Pembuatan Vco (Virgin Coconut Oil) Dari Kelapa 
p-ISSN : 2548-8783

e-ISSN : 2548-8791

Hijau Dan Kelapa Hibrida Dengan

Metode Dingin. Jurnal Hutan

Tropis, 12(31).

Yahya, M. (2015). Kaji eksperimental unjuk kerja pengering dehumidifikasi terintegrasi dengan pemanas udara surya untuk mengeringkan temulawak. Jurnal Teknik Mesin ISSN 20894880, 4(2). 